\title{
UMA DIALOGIA ENTRE OS DIREITOS HUMANOS E A ÉTICA BIOCÊNTRIA: A TERRA PARA ALÉM DO “ANTROPOCENO”
}

\author{
A DIALOGIC BETWEEN HUMAN RIGHTS AND THE BIOCENTRIC ETICS: THE EARTH \\ BEYOND THE ANTHROPOCENE
}

Recebido: 30.09 .2019

Aprovado: 25.02.2020

\author{
Lívia Gaigher Bósio Campello \\ Pós-Doutorado em Direito do Estado pela \\ Universidade de São Paulo (USP). Professora e \\ coordenadora do Programa de Mestrado em \\ Direitos Humanos da Universidade Federal de \\ Mato Grosso do Sul (UFMS). \\ EMAIL: liviagaigher@gmail.com \\ LATTES: http://lattes.cnpq.br/9067637443861868 \\ ORCID: Https:/ / orcid.org/0000-0002-1233-1902
}

\author{
Raquel Domingues Do Amaral \\ Doutoranda em Direito pela Universidade Federal \\ de Mato Grosso do Sul (UFMS). Juíza Federal no \\ Tribunal Regional da Terceira Região. \\ EMAIL: rdamaral2013@gmail.com \\ LATTES: http://lattes.cnpq.br/8289393906454567. \\ ORCID: Https:/ / orcid.org/0000-0002-0102-3031
}

RESUMO: O presente artigo analisa a necessidade de estabelecer um diálogo entre a linguagem dos direitos humanos e a ética da ecologia profunda, visando uma mudança do significado de sujeito de direito para reduzir os efeitos negativos da atividade humana no meio ambiente na nova época geológica do Antropoceno. Nesse intuito, é estudada a importância de uma mudança cultural da sociedade através de uma aproximação do homem com a natureza. Ainda, é analisado o conceito de sujeito de direito e sua relação com a propriedade, destacando as consequências disso para a relação do ser humano com os seres não humanos. Por fim, é estudada a possibilidade de uma intertextualidade entre o artigo 225 da Constituição Federal de 1988 com a teoria "Earth Jurisprudence" de Thomas Berry. Em conclusão, foi verificada a necessidade mudança do paradigma jurídico antropocêntrico atual através de uma ética biocêntrica que busque uma harmonia entre os direitos humanos es direitos dos seres não humanos, sendo que, com esse intuito, também concluiu-se que a teoria "Earth Jurisprudence" se harmoniza com o positivismo brasileiro e com os direitos humanos. Para tanto, utiliza a pesquisa exploratória e descritiva, bibliográfica e documental, com uma análise de obras, artigos científicos e legislações. O método é dedutivo, partindo de conceitos universais, buscando-se sua particularização.

PALAVRAS-CHAVE: Antropoceno. Earth Jurisprudence. Ética Biocêntrica. Direitos Humanos. Propriedade Privada.

ABSTRACT: This present paper intends to analyze the necessity to create a dialogue between the human rights' language and the deep ecology ethics' language, with the purpose to change the legal subject's meaning to reduce the human activities' negative effects in the environment at this new geologic epoch called Anthropocene. For this purpose, we study the importance of a cultural change in society through a rapprochement of man with nature. We also analyze the legal subject's concept and its relation with the property, highlighting its consequences for the relation between human beings and non-human beings. Finally, we study the possibility of an intertextuality among 1988 Brazilian Federal Constitution's article 
225 and Thomas Berry's Earth Jurisprudence's theory. In conclusion, it was verified the need to change the current anthropocentric juridical paradigm through a biocentric ethics, that seeks an harmony between human rights and the non-human beings' rights. With this idea, it was also verified that the Earth Jurisprudence's theory harmonizes with the Brazilian positivism and the human rights. For this, it was used the exploratory and descriptive, bibliographic and documental research, with an analysis of books, scientific articles and legislations. The method is deductive, starting from a universal concept until its particularization.

KEYWORDS: Anthropocene. Earth Jurisprudence. Biocentric ethics. Humans Beings Private Property.

SUMÁRIO: 1 Introdução 2 O “Antropoceno" 3 A Terra, os Humanos, o Tempo e o Lugar 4 O Ser Humano e o sujeito de direito 5 É possível uma intertextualidade do Direito Fundamental ao meio ambiente equilibrado previsto no artigo 225 da Constituição brasileira com a teoria "Earth Jurisprudence" de Thomas Berry? 6 Conclusão 7 Notas de Referência

\section{Introdução}

Este artigo pretende abordar a necessidade de se estabelecer uma dialogia entre a linguagem dos direitos humanos e a linguagem da ética ecológica profunda com a ressignificação da categoria sujeito de direito, como um caminho para minimizar os efeitos nefastos que as atividades humanas têm causado ao meio ambiente nesta nova Época que vem sendo denominada "Antropoceno".

Nessa linha, busca enfatizar a urgência de uma mudança cultural em nossa sociedade a partir da reaproximação do ser humano com a Terra e do aprendizado com a visão de mundo dos povos originários. Pretende-se demonstrar, em breve retrospecto, o conceito de sujeito de direito no pensamento jurídico ocidental e sua estreita ligação com a evolução do direito de propriedade, com realce nas dificuldades éticas e filosóficas que essa visão de mundo impõe à relação do ser humano com os outros seres não humanos. Por fim, vislumbra-se a possiblidade de uma intertextualidade entre o artigo 225, parágrafo primeiro, incisos I a VII, da Constituição Federal de 1988 (CF/88), que prevê o direito fundamental ao meio ambiente equilibrado e a teoria jus filosófica de Thomas Berry denominada "Earth Jurisprudence" e desenvolvida pelo professor Peter D. Burdon, como um caminho hermenêutico para harmonização dos direitos humanos com a ética ecológica profunda.

Embora a proteção ao meio ambiente em nosso ordenamento fundamente-se no paradigma jurídico antropocêntrico, pretende-se extrair do enunciado "meio ambiente ecologicamente equilibrado" no caput artigo 225, da Constituição Federal, bem como das regras contidas nos incisos I a VII e no parágrafo primeiro do mesmo dispositivo legal o valor "integridade ecológica" proposto por Peter D. Burdon como vetor valorativo de interpretação das normas jurídicas que estabeleçam contato com o interesse de proteção ambiental.

O estabelecimento de um eixo axiológico, pautado no conceito de integridade ecológica, demonstra-se relevante para realçar o dever fundamental de proteção ao meio ambiente fora do clássico esquema contratual de reciprocidade entre direitos e deveres.

Objetiva-se ainda destacar o dever fundamental de proteção ambiental para além da titularidade subjetiva, de modo a configurar um direito-dever, objetivo de solidariedade, na linha proposta por José Casalta Nabais. Um direito-dever que vincula não só a pessoa natural e a pessoa jurídica de direito privado em seu status de proprietários e usuários dos recursos naturais, como também o Estado em suas funções de legislar, instituir políticas e prestar jurisdição. 
Ao se verificar a possibilidade de identificação do valor "integridade ecológica" no caput do artigo 225 da CF/88, bem como nas regras contidas nos incisos I a VII do parágrafo primeiro do mesmo dispositivo legal, almeja-se evidenciar, no ordenamento jurídico, a base normativa constitucional para o reconhecimento do valor intrínseco aos seres não humanos, que deve servir de parâmetro para a interpretação das normas infraconstitucionais.

A fim de alcançar os objetivos mencionados, utilizar-se-á pesquisa exploratória e descritiva, bibliográfica e documental, com uma análise por meio de obras, artigos científicos e legislações. O método de abordagem será o dedutivo, partindo-se de conceitos gerais até sua particularização.

\section{0 "Antropoceno"}

Em 1885, o nome Holoceno foi adotado pelo Congresso Geológico Internacional em Bolonha para nominar a época geológica pós-glacial dos últimos dez a doze mil anos (CRUTZEN; STOERMER, 2000). Vários cientistas passaram a estudar a influência do ser humano nas alterações ambientais; em 1873, Antonio Stoppani classificou as atividades da humanidade como uma "nova força telúrica que no poder e na universalidade pode ser comparada às forças maiores da Terra" (STOPPANI, 1873). Stopanni não só definiu o antropozoico, como também demonstrou, pelas leis da estratigrafia - ramo da geologia que estuda a natureza dos estratos das rochas ao longo do tempo - que as rochas formadas durante a existência humana apresentavam características que indicavam que a humanidade influenciou na transformação dos processos sedimentares da Terra; por isso definiu esse período, cujo marco inicial era o início da idade da pedra, como período antropozoico. Apesar de muito bem elaborada, a teoria de Stopanni caiu no esquecimento por muitos anos (RULL, 2017); somente no século passado a questão voltou a ser discutida e os cientistas passaram a denominar o antropozoico de Stoppani de "Antropoceno".

Inicialmente, por rigor científico, vale trazer a advertência de V. Rull no sentido de que é um equívoco científico na atualidade o amplo uso do vocábulo "Antropoceno" como se já fosse considerado o nome oficial da atual época geológica. Esclarece que o temo "Antropoceno" ainda não foi formalizado para nominar a atual época geológica, portanto deve ser usado entre aspas. 0 procedimento de aprovação do termo "Antropoceno" ainda está em estágio muito inicial do protocolo ICS (Comissão Internacional sobre Estratigrafia (ICS) para aprovação e ratificação (RULL, 2017).

V. Rull esclarece que o marco original para a definição do período, que se pretende denominar "Antropoceno", foi estabelecido na segunda metade do século XVIII, início da Revolução Industrial, caracterizado pelo aumento da concentração de $\mathrm{CO} 2$ na atmosfera. Com a descoberta dos combustíveis fósseis, a humanidade passou a ter disponível 40 vezes mais energia no período de 1800 a 2000, o que causou grandes mudanças nos ecossistemas da Terra. A produção agrícola e de artefatos aumentou 50 vezes, a população de humanos - que no início da Revolução Industrial era de um bilhão - passou para seis bilhões. A concentração de CO2 aumentou, neste período, cerca de 280 a 380 ppm. Nesse sentido, V. Rull ressalta que o período mais crítico foi após a Segunda Guerra Mundial, durante a fase conhecida como a "Grande Aceleração", em que todos os indicadores da atividade humana experimentaram uma aceleração sem precedentes. A população humana foi aumentada em 3 bilhões em apenas 50 anos e a produção econômica multiplicada por 15 durante o mesmo período, bem como o número de veículos automóveis que foram aumentados de 40 para 700 milhões (RULL, 2017).

São considerados por Crutzen e Stoermer (2000, pp. 17-18) marcadores do "Antropoceno": a) a presença das partículas chamadas "cinzas volantes", liberadas para a 
atmosfera pela combustão de combustíveis fósseis, que ficam acumuladas em sedimentos e lençóis de gelo; b) bem como o acúmulo de elementos radioativos como por exemplo isótopos de carbono (14C), plutônio $(239+249 \mathrm{Pu})$, chumbo (210P) ou césio (137Cs); c) alteração nos sedimentos fósseis do fundo dos lagos causada pela eutrofização, ou seja, crescimento descontrolado das algas e plantas aquáticas, devido à grande concentração de nitrogênio e fósforo pelo uso excessivo de adubo e fertilizantes; d) outro potencial marcador estratigráfico é o plástico e materiais sintéticos, inexistentes antes da industrialização, mas presente nos sedimentos mais recentes.

V. Rull (2017, pp. 8-11) registra que haviam várias correntes científicas defendendo períodos diferentes para o termo inicial do "Antropoceno", entretanto acabou prevalecendo a corrente que defende o início do "Antropoceno" em 1945. Esse consenso científico foi construído recentemente no 35 Congresso Geológico Internacional, realizado na Cidade do Cabo em agosto de 2016. O Anthropocene Working Group (AWG) sugeriu também que o melhor estratigráfico para o "Antropoceno" é o aumento de plutônio gerado pelas explosões atômicas.

Para Schimelpfenig, a questão mais preocupante do período chamado de "Antropoceno" é a crescente extinção de espécies; o autor observa, com base em dados de Chivian e Bernstein, que a taxa suportável de perda é de uma a cinco espécies por ano, todavia, desde o século passado, essa taxa acelerou para 1.000 a 10.000 vezes (CHIVIAN; BERNSTEIN, 2017). Relata com base em dados de Bren d'Amour et al (2017) que:

de 1850 a 2000, a proporção de terra usada para o cultivo aumentou de $14 \%$ para $38 \%$, enquanto a cobertura florestal encolheu de $25 \%$ para $20 \%$. A urbanização (incluindo estradas e outras infraestruturas interurbanas) removeu cerca de 3,4 milhões de hectares por ano de terra da produtividade biológica, embora se preveja que esta desacelere para 1 milhão de hectares por ano de 2010 a 2030. No entanto, a terra perdida para urbanização é, em média, 1,8 vezes biologicamente mais produtiva do que a média da terra, então o custo é maior do que os valores brutos indicam (D'AMOUR; REITSMA; BAIOCCHI et al, apud SCHIMELPFENIG, 2017).

Ademais, além da acelerada extinção (JONAS, 2006) de espécies, Schimelpfenig (2017) adverte para o aumento do risco de pandemias e de colapsos das grandes cidades em razão das alterações climáticas.

A ciência já não nega que a atividade humana alterou de forma substancial todos os aspectos naturais do Planeta, criando uma situação de extremo risco não só para as outras espécies, como para a própria espécie humana. Todas essas alterações geológicas, climáticas, na fauna, na flora foram motivadas mais por um desejo hedônico de produtividade e comodidade do que por necessidade da autorrealização de nossa espécie. A criação de tão grave risco pelo exercício desse poder telúrico nos imputa uma responsabilidade proporcional, pois poder sem responsabilidade é tirania, assim a observação de Jonas nunca foi tão necessária:

Tudo isso se modificou decisivamente. A técnica moderna introduziu ações de uma tal ordem inédita de grandeza, com tais novos objetos e consequências que a moldura da ética antiga não consegue mais enquadrálas. (...) Decerto que as antigas prescrições éticas 'do próximo' - as prescrições da justiça, da misericórdia, da honradez etc. - ainda são válidas, em sua imediatidade íntima, para a esfera mais próxima, quotidiana, da interação humana. Mas essa esfera torna-se ensombrecida pelo crescente domínio do fazer coletivo, no qual o ator, ação e efeito não são mais os mesmos da esfera próxima. Isso impõe à ética, pela enormidade de suas 
forças uma nova dimensão, nunca sonhada de responsabilidade (JONAS, 2015, p. 39).

Essa responsabilidade nos chama a uma ressignificação ética e da própria noção de sujeito de direito, mas o avanço jurídico nesse sentido tem de ser precedido por uma mudança cultural. Qualquer alteração profunda e eficaz em nossa cultura, rumo à ecologia profunda exige uma revisão da narrativa histórica antropocêntrica, uma nova cosmogonia, como propôs Berry (1988), que nos advertiu no sentido de que a mudança para ser eficaz deve ir para além da cultura contemporânea.

Devemos voltar ao imperativo genético do qual as culturas humanas emergem originalmente e do qual elas nunca podem ser separadas sem perder sua integridade e sua capacidade de sobrevivência. [...] precisamos inventar ou reinventar uma cultura humana sustentável descendo para nossos recursos intuitivos são pre-racionais. Nossos recursos culturais perderam a integridade. Eles não são confiáveis. O que é necessário não é a transcendência, mas a insciência, não o cérebro, mas o gene (BERRY, 1988, p. 207).

Plotkin (2011), ao comentar esse trecho da obra de Berry (1988), observa que a chave para nossa sobrevivência e evolução não reside na consciência e na racionalidade, mas está no que subjaz à consciência. Trata-se de uma religação com a terra naquilo que produziu a cultura humana em sua origem, no nível genético. O autor explica que a referência de Berry (1988) à codificação genética deve ser compreendida no contexto de sua formação filosófica de eco teólogo e não de um cientista natural; para ele, a codificação genética dá forma tanto ao nosso corpo físico, quanto à nossa psique, pois é primária e fundacional das nossas tradições culturais (PLOTKIN, 2011).

Podemos citar como exemplo dessa renovação da cultura filosófica, ético e jurídica antropocêntrica a Constituição do Equador de 2008, que buscou sua legitimidade substancial na cultura ancestral Sumak Kawsay/Buen Vivir (ARTEGA-CRUZ, 2017). Com efeito, Artega-Cruz cita Luis Macas para explicar o sentido de Buen Vivir na cultura andina:

la vida en excelencia material y espiritual. La magnificencia y lo sublime se expresa en la armonía, en el equilibrio interno y externo de una comunidad. Aqui la perspectiva estratégica de la comunidad en armonía es alcanzar lo superior [...]. La convivencia es posible en tanto existan los consensos y la voluntad y las condiciones para lograr la armonía en la comunidad, obviamente la comunidad y la naturaleza. Estas formas de relaciones determinan las formas y los sistemas de vida en los seres humanos. Es decir que somos colectivos. Todos los pueblos originarios, incluso en el occidente, nacieron así. Luego nos individualizan, nos ciudadanizan (MACAS, 2010, p.14).

A lição que aprendemos com a experiência equatoriana é que os povos originários guardam a chave da porta que nos permitirá aquela insciência do gene de que fala Berry (1988) para nos despirmos do pesado escafandro da racionalidade que tem nos apartado da Comunidade Terrestre e nos condenado a uma vida insalubre voltada apenas para a produção e consumo. Boyd (2017), ao comentar a Constituição do Equador, exalta-a como uma Carta extraordinária, que traz no coração a filosofia indígena do Sumak Kawsay, cujo ideal opõe-se ao capitalismo industrial, à subjugação da natureza, à busca do crescimento econômico sem fim e à 
influência corrosiva do consumismo. O Buen Vivir promove ações como a agricultura orgânica, a energia renovável, o ecoturismo, a reciclagem como base para uma economia que visa o florescimento das pessoas, das comunidades e da natureza.

\section{A Terra, os humanos, o tempo e o lugar}

Uma das características da modernidade foram os êxodos das áreas rurais para os grandes centros urbanos com a desconexão do ser humano da terra. As tradições legadas pela ancestralidade, como as festas que marcavam o suceder das estações e as colheitas, os rituais de passagem, foram se perdendo. Nos subúrbios industriais, a massa desgarrada da terra e recrutada para as fábricas não teve mais tempo para as antigas celebrações da vida. Esse desgarramento da ancestralidade, da terra e dos rituais de passagem afetou a própria identidade do ser humano moderno, que passou a ser identificado apenas com um número, um registro geral, e não mais com suas origens.

Cullinan (2011) relata que os integrantes do povo Zulu, ao se cumprimentarem, primeiramente se apresentam dizendo seu nome, depois respondem a indagação "Uphumaphi" (de onde você é?). Nas culturas Zulu e Xhosa, quando uma criança nasce, o cordão umbilical é enterrado no chão do "Krall"; o recinto onde o gado é fechado, cuja significação para aquele provo é o coração espiritual e econômico da comunidade. Por isso, nesse contexto, a saudação Zulu tem uma significação profunda, que transcende à simples investigação sobre a pátria e comunidade da pessoa, o que se busca é a compreensão do ser, a partir de suas raízes.

Ao encarecer a urgente necessidade e o sentido da conexão com a natureza, Cullinan (2011) conta-nos que quando uma criança Karen nasce, o seu pai pega a placenta e o cordão umbilical, vai até a floresta, onde escolhe a árvore mais frondosa e oferece-lhe o cordão umbilical e a placenta, colocando-os na dobra de um galho. Esse ritual é cheio de profundas significações para o povo Karen, a árvore representa a vida, o bem-estar e a longevidade e, ao receber a oferenda, torna-se a guardiã vitalícia de um lembrete para a criança Karen que nasceu, vai lembrar-Ihe sempre que seu bem-estar está visceralmente ligado à saúde e bem-estar da árvore, que representa toda a Natureza. Quando a criança crescer, o pai a tomará pela mão e a levará até a sua árvore, para que saiba de sua responsabilidade e cuidado para com a sua árvore, que ali representa o mundo (THONGMARK; HULSE, 2011).

Cullinan (2011) pondera que, diante da grave crise de governança ambiental que vivemos, temos muito a aprender com a grande sabedoria dos povos indígenas, pois muitos desses povos vivem há milhares de anos no mesmo lugar, sem causar degradação. Além disso, padecemos de escassez de ideias novas, criativas e plausíveis sobre como melhorar nosso relacionamento com o planeta Terra, uma questão que é tão antiga como a própria humanidade e que os povos tradicionais podem nos ensinar (CULLINAN, 2011).

O ritual do povo Karen acima relatado, traz-nos profundos ensinamentos. Primeiramente, a noção de que fazemos parte de um mundo natural com o qual mantemos uma relação sistêmica e não hierárquica. Para a criança Karen, o seu o bem-estar depende do bemestar da árvore, que representa o mundo. A metáfora da árvore é linda, não importa quanto ela cresça e torne-se grande, o quanto os seus galhos ascendam à glória, eles só estarão lá, porque existem raízes fincadas na terra, que os nutrem e dão-lhe estabilidade. As raízes nos alimentam e nos dão a verdadeira segurança, quando perdemos nossas raízes, nossas referências ancestrais, tornamo-nos vulneráveis às doenças da sociedade de massas. Há ainda a mensagem do amor mundi (ARENDT, 2007), aquele amor que faz com que os seres humanos cuidem do mundo. No ritual Karen da natividade esse cuidar do mundo é algo visceral, é cuidar de si próprio, na medida 
em que a criança Karen se vê como uma extensão e uma parte do mundo natural representado pela árvore, que guardou seu cordão umbilical.

Esses rituais são muito poderosos, operam naquele nível abaixo da consciência de que fala Berrey (1988), fortalecem os vínculos com a Terra, com o lugar, e a noção de pertencimento. A desconexão dos ser humano com o lugar, com os mitos, com a ancestralidade e com a noção de tempo cíclico foi uma imposição da modernidade, que Ihe outorgou uma ontologia produtiva, em que o tempo é escasso e monetizado. O tempo deixou de ser uma dimensão da vida para ser o preço da produção. Nesse mundo onde o tempo fluiu fatalmente para um devir incerto, fomos apartados do seio da natureza, da beleza dos mitos e da cosmogonia do constante renascer, do suceder das estações, da planta que morre sob a neve do inverno e cujo bulbo adormecido se prepara para desabrochar as flores da primavera, da serpente que abandona a velha pele e renova-se, da lagarta que jaz no casulo para renascer como borboleta. Essa narrativa de um tempo cíclico harmoniza a relação do ser humano com a natureza e, sobretudo, lega-nos a esperança de renovação.

Para Schimelpfenig (2017) a ontologia holística representa um desejo inconsciente de reencontrar esse tempo mítico e o curso do mundo natural, do qual fomos apartados para que, inconscientes de nossa ancestralidade, nos reduzíssemos apenas a um meio de produção. Isso lembra o homo faber de que fala Arendt (2007), um ser humano programado para produzir e consumir em um ambiente artificial onde a natureza passou a ser vista como uma inimiga ou mero instrumento para gerar riqueza.

A ecologia profunda propõe-nos a reconexão com a Terra, com os outros seres pela nossa ancestralidade. Berry (1988) escreveu que nossa codificação genética nos "guia durante toda nossa existência, uma orientação manifestada através da espontaneidade dentro de nós" (PLOTKIN, 2011). Advertiu, entretanto, além dessa codificação genética, que precisamos ir à Terra, à fonte de onde viemos e pedir a sua orientação, pois a Terra carrega a estrutura psíquica, a forma física de cada ser que vive no Planeta. Além da terra, precisamos ir ao Universo e inquirilo sobre as questões básicas de nossa realidade, sobre nossos valores. O Universo e a Terra são as referências do nosso próprio ser, um ser que não é superior aos outros, mas irmanado pela nossa ligação umbilical à Terra (PLOTKIN, 2011).

Morin também nos conclama a uma reforma do pensamento, que passa pela nossa religação com a Terra e o universo (MORIN, 2015); essa religação profunda com a Terra é a condição inicial para reformamos nossa cultura e daí então mudarmos os paradigmas ético e jurídico com a ressignificação da natureza jurídica da Terra.

David R. Boyd nos alerta no sentido de que esse reconhecimento da nossa ligação com a Terra e com os outros seres em uma relação igualitária é a condição para protegermos o meio ambiente:

Proteger o meio ambiente é impossível se continuarmos a afirmar a superioridade humana e a propriedade universal de toda a terra e vida selvagem para buscar o crescimento econômico sem fim. A estrutura dominante hoje e o sistema legal que a apoia são autodestrutivos. [...] Precisamos de uma nova abordagem baseada na ecologia ética. Os seres humanos são apenas uma espécie entre milhões, tão biologicamente dependentes como qualquer outra nos ecossistemas que produzem água, comida e um clima estável. Somos parte da natureza: não independentes, mas interdependentes (BOYD, 2017, p. 29). 
Como pontuado por Boyd (2017), a mudança que precisamos envidar para proteger o meio ambiente de um futuro catastrófico, passa necessariamente pelo caminho de uma nova ética ecológica, que reveja o conceito de sujeito de direito e o próprio direito de propriedade.

\section{0 ser humano e o sujeito de direito}

Apesar de o direito ao meio ambiente saudável só ter sido previsto no plano internacional em 1972, na Declaração de Estocolmo, atualmente é reconhecido como um direito humano em 92 Constituições (BOYD, 2017). Há um consenso entre as nações em reconhecer que, para o ser humano usufruir os direitos civis e sociais, necessita de um meio ambiente saudável.

Nessa linha, em 28 de julho de 2010, a Assembleia Geral das Nações Unidas adotou a Resolução n. 64/292, declarando que: "a água potável e o saneamento são um direito humano essencial para o pleno desfrute da vida e de todos os outros direitos humanos" (UN, 2010). A Resolução n. 64/292 "convoca os Estados e organizações internacionais a fornecer recursos financeiros, capacitação e transferência de tecnologia, particularmente aos países em desenvolvimento, na ampliação dos esforços para fornecer água potável e saneamento seguro, limpo, e acessível para todos" (UN, 2010).

Em 30 de setembro de 2010, o Conselho de Direitos Humanos das Nações Unidas (UNHRC) afirmou e esclareceu essa decisão, declarando que o direito à água e ao saneamento já existia como decorrência do direito a um padrão de vida adequado e que por estar contido nos tratados de direitos humanos existentes é vinculativo, de modo que os Estados tem a responsabilidade primária de assegurar a plena realização deste direito (TRIGUEROS, 2012).

Como se verifica, a Resolução n. 64/292 afirmou a existência de um direito humano à água, um direito que pretende resguardar a dimensão biológica do ser humano. Analisando esse direito pela lente do paradigma jurídico antropocêntrico, é fácil enxergar em sua contraface o dever dos Estados de proteção dos rios, dos aquíferos e dos mananciais. Todavia, essa proteção é feita em consideração ao ser humano e, por via oblíqua, protege os seres que vivem na água ou que dela necessitam. Mas, o que nos impede de romper com esse paradigma epistêmico e propor que, além do direito dos humanos à água potável, outros seres também tenham garantido o direito de dessedentar de uma água pura? Por que não asseguramos em nossas leis o direito dos integrantes da ictiofauna a uma água limpa e salubre? Por que os próprios aquíferos, rios, lagos, mananciais e nascentes não têm o seu direito assegurado em lei para fluírem livres de contaminação para manter sua integridade em harmonia com todos os seres? Em que medida o reconhecimento desse direito a esses seres prejudicaria o nosso direito humano à água garantido na Resolução n. 64/292?

Por que não poderia haver um direito objetivo de proteção da água do planeta, por que essa necessidade de subjetivação, de titularidade humana? E se não pudermos pensar na existência de direito sem a subjetividade, por que o rio, o peixe que nele habita e o urso que se alimenta do peixe não podem ser titulares de um direito à potabilidade da água do Rio?

Assim como a água potável é necessária para a autorrealização do animal humano, cujo corpo físico é composto, em média, por 75\% de água (DE MIRANDA, 2004), igualmente o Rio, o Peixe e o Urso precisam da água para se autorrealizarem.

Para entendermos a dificuldade de se pensar o direito fora da moldura antropocêntrica, temos de voltar os olhos para história e compreender como surgiu o conceito de direito subjetivo, e ter consciência de que ele nem sempre existiu, e, assim, refletir sobre sua estreita ligação com o conceito de propriedade e consequente de coisificação da Terra. 
Douzinas (2009) adverte que há um derradeiro e crucial aspecto na genealogia dos direitos humanos, sem o qual não compreenderemos a teoria da justiça na modernidade, é o momento em que houve a mutação da tradição clássica e medieval do direito objetivo para o direito subjetivo, com a criação do indivíduo soberano. Cita John Finnis (1980), que situa o ponto histórico do nascimento da subjetivação do direito, quando Francisco Suarez no texto De Legibus, no século XVII, refere-se ao jus como "algo benéfico - um poder - que uma pessoa tem", destoado de Tomás de Aquino (1991), que definia o jus como "aquilo que é justo em uma determinada situação". A partir de então, o direito passa ser visto como um poder, uma liberdade possuída por um indivíduo.

Com base nos estudos de Michel Villey (2009), Douzinas (2009) esclarece que o nascimento do homem moderno e dos direitos individuais têm suas raízes na escolástica católica, que atribuiu uma natureza essencial ao homem por ter sido criado por Deus, Imago Dei. Credita aos nominalistas franciscanos Duns Scotus e Guilherme de Ockham, no século XIV, o desenvolvimento da noção de individualidade como expressão máxima da criação. Segundo Douzinas (2009), os nominalistas franciscanos, mormente Guilherme, argumentavam que o controle exercido pelos indivíduos sobre suas próprias vidas era uma forma de "dominium" ou propriedade, um tipo de propriedade natural não garantida em lei, mas decorrente do fato básico da vida humana, uma vez que o homem foi criado a imagem de Deus, este legou-lhe os direitos naturais como uma dádiva. Nesse contexto, o direito natural objetivo foi convertido em direito individual subjetivo. Doravante, o pensamento o jurídico e político do ocidente colocou o indivíduo em uma posição central, com seus poderes e direitos (VILLEY, 2009).

No mesmo sentido, relata Douzinas (2009) que Grotius (2005) atribuiu a titularidade do jus à pessoa, mas foi além, colocou como fundamento do direito a lei, que, para ele, correspondia a racionalidade do ser humano; abandonando, assim, a tradição clássica e cristã do direito natural. Este foi marco na cultura jurídica ocidental em que a natureza, percebida como universo físico, é expungida da humanidade. A partir de então a natureza é esvaziada do valor que lhe foi dada os estoicos, da alma animista dos medievais, e torna-se uma força ameaçadora e hostil (GROTIUS, 2005).

Villey (2009) conjectura que Hobbes tenha lido os franciscanos nominalistas para formar sua concepção de direito subjetivo. Ressalta que Hobbes (1996) enfrentou a questão do direito subjetivo na fonte, desconstruindo a teoria política de Aristóteles, onde estavam as raízes da antiga concepção de direito. Hobbes cria uma nova concepção de sociedade profana e racional, totalmente independente das escolásticas e dos clássicos. Como um pensador moderno, forja uma ciência social com base no paradigma da física moderna, abandona o caráter especulativo da ciência e assume-se o utilitarista, ou seja, almeja uma ciência que tenha os fins práticos de dominar a natureza. Hobbes concebe um novo estado da natureza, antagônico ao de Aristóteles, ou seja, em que os homens estariam separados, sem laços sociais naturais e absolutamente livres para defender seus interesses. Assim o jus no estado de natureza é definido por Hobbes nos seguintes termos (VILLEY, 2009):

O direito de natureza geralmente chamado de jus naturale é a liberdade que cada homem possui de usar seu próprio poder, da maneira que quiser, para a preservação de sua própria natureza, ou seja, de sua vida; e, consequentemente, de fazer tudo aquilo que seu próprio julgamento e razão Ihe indiquem como meios adequados para este fim (HOBBES apud VILLEY, 2009, p. 697).

Veja-se que direito o natural preconizado por Hobbes é totalmente diferente do direito natural tomista. Trata-se de um direito subjetivado, sem limites para seu exercício, absoluto, em 
um estado de natureza onde inexiste sociedade ou lei disciplinando as relações sociais. Enquanto para Aristóteles, o direito era uma partilha de bens em uma sociedade naturalmente constituída, Hobbes fundamenta o direito em apenas uma lei moral: a consciência de autopreservação de cada indivíduo. No direito natural de Hobbes inexiste noção de justiças comutativa e distributiva. Enquanto, na teoria clássica, o direito de cada um era uma parte das coisas sociais a serem partilhadas, ou seja, uma fração limitada, Hobbes (apud VILLEY,2009) destaca que o direito subjetivo no estado de natureza pode ser exercitado de forma ilimitada no interesse de preservação do seu próprio titular (HOBBES apud VILLEY, 2009).

Com Hobbes, esse direito subjetivo e natural do indivíduo é colocado definidamente na base do sistema, sobre ele repousarão os pactos e os contratos, este a cessão recíproca de direitos, aquele uma renúncia. No pacto repousa toda ordem jurídica positiva que doravante se instaurará (HOBBES apud VILLEY, 2009). A natureza fica completamente alijada desse sistema de direito, cuja construção tem como finalidade domá-la e dominá-la, uma vez que após constituído o corpo social, no estado civil, esse direito subjetivo individual, no dizer de Villey (2209), "reaparecerá metamorfoseado nas formas de dominium (dominion) da proprietas (property)" (HOBBES apud VILLEY, 2009) tão necessários, quanto o carvão, para acelerar os motores da modernidade, que apartará quase definidamente o ser humano da natureza, o direito dos valores e a cultura do ambiente.

Douzinas (2009) pontua que o sujeito na filosofia, a pessoa no Direito e o Eu na psicologia constituem a principal característica definidora da modernidade e perscruta o significado do sujeito jurídico (DOUZINAS, 2009). Pontua que o direito natural clássico e as primeiras definições modernas do direito estabeleceram normativamente o que é considerado tipicamente humano e passaram a derivar suas prescrições normativas "a partir da natureza e das necessidades do que denomina "humanidade'" (DOUZINAS, 2009). Todavia, a inclusão de entes na classe denominada 'humanidade' para fins de consideração moral e jurídica, é cambiante no tempo e nas culturas, o que fica evidente ao considerarmos que pessoas humanas escravizadas foram excluídas dessa classe ao longo da história e tratadas como coisa. Mas, curiosamente, na Idade Média, animais foram partes em processos criminais e sob a acusação de cometerem delitos, eram levados aos tribunais, condenados e punidos dentro da ritualista processual da época (DOUZINAS, 2009).

Douzinas lança vários questionamentos acerca da titularidade do direito subjetivo ser restrita aos seres humanos: a existência do direito pressupõe necessariamente a titularidade por uma pessoa humana? Apenas o ser humano pode ocupar a posição de sujeito? E quanto aos animais? (DOUZINAS, 2009). Aponta para o fato de empresas e outras pessoas jurídicas nãohumanas terem, ao longo de séculos, conquistado seus direitos legais. Douzinas (2009) cita o famoso artigo de Christopher Stone (2009), em que reivindica a titularidade de direitos para árvores e parques. Menciona também o trabalho e Marie-Angêle Hermitte, "Le concept de diversité biologique et la création d'un status de la nature", autor francês que pleiteou a transformação de áreas verdes em sujeitos de direito. Adverte que a subjetividade jurídica não foi outorgada exclusivamente aos humanos, pois se verifica seu emprego com base em critérios econômicos, o que demonstra que não se tem um critério rígido ontológico, que se fundamenta mais em conveniência. Critica o fato de o sentido de humanidade não estar conclusivamente estabelecido, e atribui isso ao fato de termos abandonado o pensamento clássico e aceitado "um frágil sentido de Direito Natural a la Hart" (HART, 2009).

Comparato (2006), por sua vez, explica que a ideia de que os indivíduos e grupos humanos podem ser reduzidos a um conceito ou categoria geral, que a todos engloba, é de elaboração recente na História. Como observou um antropólogo, nos povos que vivem à margem do que se convencionou classificar como civilização, não existe palavra que exprima o conceito de ser humano: os integrantes do grupo são chamados "homens", mas os estranhos ao grupo são

44 | Revista Brasileira de Direito Animal, e-issn: 2317-4552, Salvador, volume 15, n. 01, p.35-60, Jan-Abril 2020 
designados por outra denominação, a significar que se trata de indivíduos de uma espécie diferente (COMPARATO, 2006).

O autor relata que, na filosofia grega, Platão considerava que a essência do ser humano está na alma (COMPARATO, 2006), ao contestar o idealismo transcendental de Platão, Aristóteles identificou como elemento comum a todos os seres humanos o agir racional (ARISTÓTELES apud COMPARATO, 2006). Já para os sofistas e depois para os estoicos, o elemento comum a todos os seres humanos seria a natureza, physis, como princípio universal organizador do cosmos. Em Roma, encontra-se a noção de humanidade na oposição entre máscara teatral (papel social de cada indivíduo) e a essência individual de cada ser humano, que, posteriormente, veio a ser designada de personalidade. No cristianismo, a humanidade da pessoa decorre de sua dimensão espiritual, imago dei, tendo sido a partir dessa concepção que se iniciou a elaboração do princípio da igualdade entre os seres humanos. Finalmente, Kant atribui uma dignidade inerente a todos os seres humanos (KANT apud COMPARATO, 2006).

O sujeito jurídico, tal qual conhecemos, nasceu na filosofia de Kant. A centralidade do sujeito, com a objetivação do mundo é firmada na racionalidade cartesiana, mas foi a antropologia teórica kantiana que proscreveu a relação entre a natureza e a humanidade, sistematizando o pensamento cartesiano, para firmar o sujeito como detentor de linguagem e consciência, decorrendo desta última a intencionalidade, autocompreensão e a liberdade (DOUZINAS, 2009).

Como ressaltado, segundo Heron José de Santana Gordilho e Raissa Pimentel Silva (2016), o pensamento kantiano influencia até hoje a estrutura jurídica das relações entre os seres humanos e não humanos:

Para Kant, filósofo que ainda hoje exerce uma enorme influência no mundo jurídico, é impossível uma relação jurídica entre os homens e os animais, uma vez que o Direito é bilateral - para cada direito corresponde um devere como os animais não possuem nem direitos nem deveres, isso não é possível. (GORDILHO, SILVA, 2016, pp. 1-19)

A partir de então a humanidade é arrancada de seu habitat natural e atirada ao hedonismo, a uma busca sem fim (DOUZINAS, 2009) de satisfação absoluta; enquanto a natureza, por sua vez, passa a ter função de mero instrumento dos intermináveis anseios humanos.

Para Morin (2015) a compreensão da condição do ser humano passa pela reflexão de sua historicidade, inserida na narrativa do nascimento do universo há bilhões de anos e que originou nosso sol e a aventura da vida na Terra, em cuja linhagem dos mamíferos surgem os primatas e uma estranha ramificação de bípede que vai se direcionar para uma nova aventura: a hominização e consequente devir humano até a presente globalização que não é senão o estado atual de uma aventura desconhecida (MORIN, 2015). Ressalta que o ser humano é complexo, ou seja, é trinitário: "indivíduo-espécie-sociedade", esses três termos são inseparáveis em um circuito recursivo e holográfico, de modo que o indivíduo não é apenas uma pequena parte da sociedade, o todo de sua sociedade está presente nele, na linguagem e na cultura. Um indivíduo não é apenas uma pequena parte da espécie humana. O todo da espécie está presente nele, em seu patrimônio genético, em cada célula, está presente até mesmo em sua mente, que depende do funcionamento do cérebro. Portanto, o ser humano é simultaneamente biológico, psíquico, cultural, social e histórico (MORIN, 2015).

Se nos igualamos aos demais seres humanos pela nossa dimensão cultural e pela linguagem, pela nossa dimensão biológica, pelo "animal laborans", de Hannah Arendt, estabelecemos uma experiência comum com os seres não humanos. Arendt (2007) identifica o labor como o trabalho do nosso corpo para mantença das necessidades vitais. Precisamos 
alimentar, nos hidratar, respirar para manutenção do aspecto biológico do ser humano. Esse labor, diferentemente do trabalho direcionado à produção, apenas ocasionalmente produz algum artefato, seu objetivo é a produção de meios para garantir a reprodução do ser humano e seus processos vitais. Arendt aponta o desprezo do ser humano em relação ao labor, e o atribui à acirrada resistência em aceitar a sua necessidade: "[...] e de uma impaciência não menos forte em relação a todo esforço que não deixasse qualquer vestígio, qualquer monumento, qualquer grande obra digna de ser lembrada" (ARENDT, 2007). Na antiguidade grega, o labor foi atribuído às pessoas proscritas do espaço público e da cidadania porque eram escravizadas. Arendt explica que o motivo da escravidão na antiguidade grega não era a mão-de-obra barata, a exploração para gerar lucro, como ocorreu na modernidade; mas, sim, uma tentativa de excluir o labor das condições da vida humana. Tudo que os homens tinham em comum com as outras formas de vida animal era considerado inumano (ARENDT, 2007).

Percebe-se que, desde a antiguidade, o ser humano resiste em aceitar a sua condição biológica, justamente aquela que nos irmana com todos os outros seres. A aceitação de que somos uma espécie que tem uma dimensão biológica é condição primordial para a compreensão de nossa existência como membros de uma comunidade terrena. Taylor (2011) adverte que compartilhamos, como os outros animais, um quarto tipo de liberdade decorrente da condição biológica. Podemos relacionar essa liberdade para a satisfação biológica a uma liberdade para o exercício do labor a que se refere Arendt (2007); isto é, a liberdade para nutrir nossas necessidades vitais, para buscar a água, a comida. Um ser humano, assim como o lobo confinado, perderá a sua liberdade de nutrir o ser biológico (TAYLOR, 2011). Desse modo, o "animal laborans" comunga de uma mesma liberdade com os pássaros, com as serpentes, com os gafanhotos, com os antílopes, com as árvores e todos os seres. Essa liberdade é condição para o exercício de todas as outras, pois é o animal laborans que sustenta o homo faber e o ser político, esses só produzirão a riqueza e a victa ativa (ARENDT, 2007), se tiverem saúde. Nessa dimensão de liberdade proposta por Taylor, um organismo é livre quando tem condições e oportunidade de promover e proteger seu bem de acordo com as leis de sua própria natureza.

O reconhecimento de nossa dimensão biológica, além de ser um ato de humildade, é um ato de inteligência, pois, assim como os outros animais não humanos, somos um organismo biológico. E antes de sermos um ser econômico e político, somos um corpo físico.

Propomos uma parábola para ilustrar o drama do animal humano. Pense em um ser humano muito rico e politicamente poderoso, que, no ápice da realização pessoal, não pudesse mais expressar sua vontade pela linguagem, porque o seu cérebro está acometido de uma doença degenerativa. Nesse caso, o cérebro, antes de ser um instrumento criativo desse brilhante homo faber, que fez fortuna fabricando um hardware e um software, que revolucionou o mundo; antes de ser a psique, a mente do homem político e genial, que dialogava com parlamentos e chefes de estado, esse cérebro era apenas células envoltas em membranas, neurônios, que precisam de água e oxigênio para a sinapse.

De repente, toda genialidade, todo poder foram apagados pela atrofia repentina das células cerebrais. Não existem ideias para gerar riqueza e poder político que não passem pela sinapse dos neurônios no organismo biológico do "animal laborans" (ARENDT, 2007). Essa é a condição que nos iguala a todos os demais seres, que nos inclui na comunidade ética, como apenas mais um sujeito, um "eu", uma pessoa, entre tantas outras que galopam pelos prados, que voam pelos céus, que cruzam os mares, que nos abriga em suas sobras e purificam o nosso ar. Essa realidade biológica nos exige a humildade e a honestidade para empreender uma ressignificação do sentido de humanidade e nele incluir todos os outros seres.

O fato de compartilharmos consideração moral com esses seres para lhes atribuir titularidade de direitos, que são básicos para suas existências, não ameaça os nossos direitos humanos; a revés, fortalece-os, na medida em que estaremos nos desincumbido do dever 
fundamental de assegurar um meio ambiente saudável e equilibrado para as gerações futuras de nossa espécie, que só existirão irmanada com as outras espécie em uma comunidade harmônica.

\section{5 É possível uma intertextualidade do Direito Fundamental ao meio ambiente equilibrado previsto no artigo 225 da Constituição brasileira com a teoria "Earth Jurisprudence" de Thomas Berry?}

Em primeiro lugar temos de entender o conceito de "Earth Jurisprudence" de Berry (2006), sendo que adotaremos a linha proposta por Burdon (2015), por considerar possível harmonizá-la com o positivismo jurídico. Peter Burdon, professor sênior da Adelaide Law School, propôs interpretar, sistematizar e desenvolver os textos jurídicos fragmentados de Thomas Berry para criar uma teoria jusfilosófica chamada Jurisprudência da Terra.

Define a "Jurisprudência da Terra" como uma filosofia emergente, que surge não só como uma resposta à grave crise ambiental, mas como um aspecto filosófico do movimento ecológico e também como uma teoria crítica do direito. Uma crítica à legitimação de relações sociais consideradas injustas pela ótica da ecologia profunda e à hierarquização dos interesses jurídicos, que foi estruturada pelo paradigma antropocêntrico. Esclarece que outros autores têm escrito sobre a "Jurisprudência da Terra" a partir dos escritos jurídicos de Berry (1988), cita Cormac Cullinan (2015) com sua obra Wild Law, ressaltando que, apesar das diferenças teóricas de sua proposta para a de Cullinan, há um ponto de comunhão preciso entre ambos, no sentido de que a sociedade se estrutura em uma ordem legal que reproduz a concepção antropocêntrica do mundo, que já não mais atende à realidade do Planeta. Assim, os estudiosos da "Jurisprudência da Terra" fazem uma crítica ao antropocentrismo e propõem novas bases para o sistema jurídico.

Cullinan (2015) trabalha a Jurisprudência da Terra a partir de uma visão de que existem princípios fundamentais que governam o funcionamento do universo e que devem ser aplicados aos nossos sistemas legais, no que concerne à disciplina das relações do ser humano com a Terra e descreve essas prescrições como a "Lei Selvagem" (CORMAC, 2015).

A primeira premissa da "Jurisprudência da Terra" é a ruptura com o paradigma antropocêntrico, segundo o qual a autorrealização do ser humano é alcançada a partir da exploração da Terra. No paradigma epistemológico biocêntrico, em que se funda a Jurisprudência da Terra, o florescimento, a plenitude e a saúde de toda a comunidade terrestre é pré-requisito para o bem-estar do ser humano, tendo em vista que nossa espécie é membro desta comunidade juntamente com milhares de outras, às quais está ligada pela dimensão biológica. A segunda premissa é a aceitação de que existe uma comunidade terrestre e que o ser humano não tem uma posição superior dentro dela, isso implica reconhecer que:

assim como Copérnico demonstrou que a Terra não estava no centro do Universo, a ciência contemporânea demonstra que o ser humano não está no centro da comunidade da Terra. E mais especificamente, os seres humanos não são os árbitros de todo o significado, sendo que nossa renúncia ao domínio epistêmico sobre a natureza fornece a base para uma nova intimidade com a Terra (BURDON, 2015, p. 47).

Quando Burdon (2015) menciona que o ser humano não é o árbitro de todo o significado, isso nos faz lembrar de que a semiótica, a linguística, que se dedicam ao estudo da linguagem dos animais, já estão estudando a inteligência dos animais fora do parâmetro antropocêntrico. Nesse sentido, Prisca Augustyn (2018) cita estudos de Herzing, que em sua 
pesquisa sobre as habilidades significantes dos golfinhos selvagens, adotou nova abordagem, não estabelecendo como parâmetro a inteligência do ser humano (AUGUSTYN, 2018). Augustyn pondera:

Parece que o século XXI finalmente reconheceu a complexidade e a sistematicidade das habilidades significantes de outros animais inteligentes, como os golfinhos. Pelo menos alguns cientistas descobriram maneiras de investigar sistemas de signos animais com uma nova atitude que é consistente com a premissa uexkülliana de que eles têm maneiras de entender o mundo que é diferente do nosso. Parece que pelo menos parte da comunidade científica está reavaliando seriamente nossos relacionamentos com outras espécies e está disposta a revisar a história (AUGUSTYN, 2018, p. 121).

Para corroborar seu pensamento, cita a seguinte fala Andreas Weber sobre a nova biologia emergente:

\begin{abstract}
Sempre pareceu como pesquisadores e cientistas modernos que estávamos negligenciando algo essencial sobre plantas e animais. É como se fôssemos cegos para precisamente o que nos levou a estudar organismos vivos em primeiro lugar. [...] Estamos negligenciando aspectos importantes da natureza, porque a ciência nos apresentou de uma forma que excluiu seu aspecto mais belo, porque se concentrou apenas em fatos objetivos, em vez de ver organismos como sujeitos. A ciência prefere abstrações e exclui todos os aspectos semióticos da vida. Essa é a causa real de todo desastre ambiental. Estamos extinguindo a vida, porque estamos perdendo seu caráter real. Podemos ser cruéis, porque nossa compreensão da vida é incompleta (WEBER apud AUGUSTYN, 2018, p. 121).
\end{abstract}

Assim como surgem a zoossemiótica, a biolinguística, também emerge o movimento "Earth Jurisprudence" como um novo direito. Burdon (2015) usa a noção de mudança de paradigma de Thomas Kuhn (2015), em que este adverte que um paradigma só pode funcionar se suas ferramentas ainda forem eficientes para resolver os problemas que ele define. Segundo a teoria de Kuhn, citada por Burdon, um paradigma entra em crise quando ideias alternativas o colocam em dúvida e apresentam uma nova estrutura de significados mais plausíveis, sugerindo um novo modelo mais viável de prática futura. Trata-se, portanto, de uma questão de adaptação (KUHN, 2015). Esclarece que nos períodos pré-paradigmáticos há uma profusão de teorias em diferentes escolas de pensamento, valores e visões de mundo que coexistem, mas só se firma um novo paradigma, quando há uma aceitação ampla do novo modelo proposto e de suas ferramentas pela comunidade. Nessa linha, pondera que os princípios imanentes ao conceito de "Comunidade da Terra" propostos por Berry (1988) já gozam de ampla aceitação na sociedade contemporânea.

Apresenta como fundamentos científicos do conceito de "Comunidade da Terra" a nova concepção de matéria trazida pela física quântica, os avanços científicos na ecologia, o conceito de autopoesis e teoria da Hipótese de Gaia de Lovelock. Salienta que mais que uma simples mudança na lei, necessita-se de uma mudança cultural para substituir o paradigma antropocêntrico pela visão de "Comunidade da Terra" (BURDON, 2015). Para essa mudança cultural, Berry (1988) propõe uma nova narrativa, com esse mister publicou em 1977 "The New Story" (BERRY, apud BURDON, 2015) e em 1988 "The Dream of the Earth" (BERRY, 1988). 
Burdon (2015) ressalta que os mitos tradicionais de nossa cultura ocidental formaram milhares de gerações, a partir de uma cosmologia centrada no ser humano, que foi herdada das nossas religiões e filosofias ocidentais, assim Berry (BERRY apud BURDON, 2015), com base na metodologia do historiador de Giambattista Vico (1976), propôs uma "nova história" cuja narrativa é estruturada em quatro eras: a) tribal-xamânica; b) religiosa-cultural; c) científicotecnológica e d) ecológica. Destaca as diferentes formas de interferência do ser humano no mundo natural durante cada um desses períodos. Essa narrativa visa trazer, em uma linguagem acessível, os novos valores ecológicos para uma mudança cultural (BURDON, 2015).

A partir da nova narrativa da "Comunidade da Terra", em que todos os seres são dignos de consideração moral e valor inerente, Burdon sistematiza a sua teoria jusfilosófica denominada "Earth Jurisprudence"; partindo dos estudos de Berry (2015) no sentido de que existem dois tipos de "leis" organizadas em uma relação hierárquica; a primeira ordem é a Grande Lei decorrente do princípio da Comunidade da Terra, enquanto a segunda ordem do direito é a lei humana, que representa o direito positivo (BERRY, 2015).

Pontua a existência de dois preceitos interpretativos que regulam a inter-relação entre a Grande Lei e a Lei humana: i) a lei humana deriva sua qualidade substancial e seu poder normativo vinculante da grande lei. Uma norma criada por autoridades legislativas humanas só tem poder vinculante se estiver de acordo com a Grande Lei, isso porque os seres humanos existem como parte de uma comunidade interconectada e mutuamente dependente, a "Comunidade da Terra"; assim, apenas as normas dirigidas ao bem comum, em cujo conceito estão incluídos todos os membros da comunidade humanos e não humanos, tem a qualidade de lei. ii) qualquer lei humana que viole a Grande Lei, é uma forma de corrupção, de modo que legitima a desobediência civil e não vincula a população (BERRY, 2015).

Como se percebe, a proposta de Burdon, com base na teoria de Berry (2006), assemelha-se a doutrina do Direito Natural, que se baseia na existência de um corpo de lei - 0 direito natural - universal e imutável. O Direito Natural foi descrito como um corpo de leis superiores que servem para aferir a moralidade das leis comuns. Na ótica clássica do Direito Natural, essa Lei Superior, universal e imutável é apreendida pelos seres humanos por intermédio da razão (BERRY, 2006).

Thomas Berry, que foi padre da ordem dominicana, concebeu os fundamentos da Jurisprudência da Terra sob a influência teórica de São Tomás de Aquino (1991). A teoria jurídica de São Tomás de Aquino (AQUINAS apud BURDON, 2015) estrutura-se em quatro tipos de leis, organizadas hierarquicamente: i) a lei eterna, as regras dadas por Deus, que governam a natureza; ii) a lei natural, dimensão da Lei Eterna, desvelada por intermédio do raciocínio, da razão; iii) a lei divina, que é a Lei de Deus revelada nas escrituras; iv) a lei humana que está na base da ordenação, consistente em regras apoiadas pela razão e articulada pelos legisladores (AQUINAS apud BURDON, 2015).

Burton demonstra a semelhança entre a Jurisprudência da Terra e a Teoria do Direito Natural de São Tomás de Aquino. A Grande Lei representa a concepção ecológica de "Comunidade da Terra" concebida por Berry. É a interconexão humana com a Natureza e a integridade ecológica da Comunidade da Terra. O termo "natureza" na Jurisprudência da Terra tem um significado diferente do modo como o termo é interpretado na Teoria do Direito natural de São Tomás de Aquino (AQUINAS, 1991). Na teoria tomista, "natureza" se refere especificamente a verdades universais derivadas da razão humana.

Tomando-se como ponto de partida a interpretação do supra princípio da "Comunidade da Terra" apresentado por Berry (2011), o planeta pode ser compreendido como uma comunidade única e interligada, de modo que a sociedade humana precisa mudar seu enfoque dos padrões normativos antropocêntricos para reconhecer a "supremacia da governança da Terra já existente" (BERRY, 2011). Para Berry (2011), a Terra é nossa mestra primária e legisladora. 
Cormac Cullinan (2003), também estudioso da obra de Berry, descreve "a Grande Lei" como "leis ou princípios que governam como o universo funciona e observa que são atemporais e unificados no sentido de que todos têm a mesma fonte. Esta Lei é manifestada no próprio universo e pode ser testemunhada por fenômenos como gravidade e alinhamento de planetas, crescimento de planetas, ciclos de dia e noite. Burdon observa que, além Cullinan (2003), Klaus Bosselmann (BOSSELMAN; TARLOCK, 1994) também defende a reconciliação entre as leis humanas e as leis da natureza, e a confirmação daquelas por estas (BURDON, 2015).

Uma indagação inquietante que vai aumentando no decorrer da leitura da obra de Burdon é sobre o conceito de "lei da natureza". O autor aponta que não há concordância na literatura científica sobre um conceito unívoco. Ao contrário, a discussão é acirrada entre as denominadas correntes necessitária e regularista. Aquela sustenta que as leis da natureza decorreriam de suas necessidades reais. Já os regularistas, argumentam que não há necessidades, mas apenas regularidades, isto é, correlações e padrões - e as leis são descrições dessas regularidades (BURDON, 2015).

Devido a essa imprecisão conceitual e ao amplo espectro de abrangência das chamadas "leis da natureza", Burdon não as adota como base para o conteúdo da Grande Lei, fundamenta o conteúdo da Grande Lei na ciência ecológica, em seus conceitos científicos e mensuráveis, como, por exemplo, integridade ecológica. Essa abordagem visa fortalecer a relação entre ciência e lei, prescrevendo normas referenciadas por informações verificáveis, como por exemplo estudo de impacto ambiental. Esclarece que o termo "integridade ecológica" emergiu como um conceito ético derivado da Ética da Terra de Aldo Leopold, já tendo sido reconhecido em instrumentos normativos como o US Clean Water Act (1972) (BURDON, 2015).

Na questão 90 da Suma Teológica, São Tomás de Aquino (AQUINAS, 1991), no artigo 3, define a lei humana como "uma ordenança de razão para o bem comum, feita por quem cuida da comunidade e é promulgada." Na teoria da Jurisprudência da Terra, o "bem comum" é diferente do conceito tomista, tendo em vista que não tem referência em um cálculo utilitário; mas, sim, à garantia de condições que tendem a favorecer a saúde e o futuro florescimento da comunidade terreal. Na teoria de Berry (2006), o bem comum está relacionado ao bem-estar da Comunidade Terrestre e não simplesmente do seu componente humano; logo, tem uma amplitude e profundidade maior que aquela proposta por Aquino (1991), pois visa à integridade ecológica e ao florescimento de todos os partícipes da comunidade terrena. A palavra "comum", em Aquino, abrange os membros da comunidade ética antropocêntrica, ou seja, os humanos, na Jurisprudência da Terra o bem almejado ganha uma maior extensão, tendo em vista a ampliação da comunidade ética que aqui alberga os animais humanos e os não humanos, as plantas, e todos os ecossistemas. O bem comum em Tomas de Aquino é fundamentado na razão humana, já na Jurisprudência da Terra o bem comum é complementado pelo uso da descrição científica, pelo reconhecimento dos padrões de "integridade ecológica" (BURDON, 2015).

Burdon (2015) conclui que a lei humana são regras, apoiadas na Grande Lei, que são positivadas pelas autoridades humanas para o bem comum de um todo abrangente, de modo que não contradiz as afirmações conceituais do positivismo jurídico, tendo em vista que assegura a autoridade presumida dos seres humanos para fazer prescrições obrigatórias para a comunidade (BURDON, 2015).

Esclarece que a linha divisória entre a "Jurisprudência da Terra" e o positivismo jurídico repousa em distinções sutis: a) a Jurisprudência da Terra busca fundamento em uma "lei superior", que é ordenada acima da lei humana, a "Grande Lei", cujo conteúdo reside no conceito de "integridade ecológica"; b) a Jurisprudência da Terra prescreve que a lei humana tenha um propósito. Essa descrição intencional da lei assemelha-se àquela oferecida por Tomás Fuller (LON, 1956), teórico da lei natural secular. A mesma intencionalidade é encontrada em Tomás de Aquino, quando na questão 90, artigo 3, diz que toda lei deve ser ordenada para o bem comum. 
Enquanto para Tomás Fuller, o propósito central da lei é o florescimento humano em sociedade. O propósito da lei humana para a Jurisprudência da Terra é o florescimento de toda a Comunidade Terrestre, da qual faz parte o ser humano, assim como os seres não humanos (BURDON, 2015).

Ressalta ainda que a "Jurisprudência da Terra" não é aplicada a todos os ramos do direito, mas apenas àqueles em que envolvem o valor de integridade ecológica, ou seja, questões que dizem respeito ao meio ambiente, a relação humano-terra, conflitos entre interesses de humanos e não humanos, por exemplo, direito ambiental, leis de planejamento, leis de gestão de recursos naturais e resíduos, de conservação ambiental e, principalmente, leis que disciplinam o direito de propriedade (BURDON, 2015).

No ordenamento jurídico brasileiro, o valor integridade ecológica proposto por Burdon, como conteúdo da Grande Lei, poderia orientar o direito ambiental, o direito administrativo, partes do direito civil, o direito urbanístico, o direito agrário, o direito tributário e em nada conflitaria com os direitos humanos já reconhecidos em nossa Carta Política.

Com efeito, a função social da propriedade e o dever fundamental de preservação do meio ambiente ecologicamente equilibrado previstos na Constituição do Brasil, respectivamente, no artigo 50, inciso XXIII e artigo 225 caput, amoldam-se perfeitamente ao valor "integridade ecológica" proposto por Peter Burdon na teoria da "Jurisprudência da Terra" como conteúdo axiológico da Grande Lei.

Nesse sentido, podemos citar o pensamento de Sarlet e Fensterseifer (2014), que destacam a centralidade dos valores ecológicos no ordenamento jurídico brasileiro:

[...] a consagração do objetivo e dos deveres de proteção ambiental a cargo do Estado Brasileiro (em relação a todos os entes federativos) e, sobretudo, a atribuição de status jurídico-constitucional de direito-dever fundamental ao direito ao ambiente ecologicamente equilibrado colocam os valores ecológicos no "coração" do Direito Brasileiro, influenciando todos os ramos jurídicos, inclusive a ponto de implicar limites a outros direitos (fundamentais ou não) (SARLET; FENSTERSEIFER, 2014, p. 241).

Um ponto crucial a se destacar neste trecho da obra de Sarlet e Fensterseifer (2014) é a referência ao direito subjetivo ao meio ambiente ecologicamente equilibrado como um "direitodever fundamental". Deflui-se que ao lado do direito ao meio ambiente equilibrado, que exsurge em nosso ordenamento como um direito fundamental do ser humano, está o dever fundamental de assegurar o equilíbrio ecológico. Para a compreensão da extensão e profundidade do conceito de dever fundamental, vale recorrer ao escólio do professor José Casalta Nabais, que considera os deveres fundamentais como uma figura jurídica e não uma mera categoria ética. Nabais (2012) ressalta que os deveres fundamentais são uma categoria constitucional própria, que se posiciona ao lado dos direitos fundamentais, constituindo um importante vetor do estatuto constitucional do indivíduo, erguido sobre a posição central da pessoa humana. De modo que os deveres fundamentais constitucionais não podem ser tratados apenas como matéria da constituição política e econômica; mas, sim, matéria dos direitos fundamentais, compreendidos estes como o conjunto de todo o estatuto constitucional do indivíduo consubstanciado na categoria direitos fundamentais. Assim, os deveres fundamentais são uma categoria constitucional própria, que expressam mediata ou imediatamente valores e interesses comunitários diferentes e contrapostos a valores e interesses individuais albergados nos direitos fundamentais (NABAIS, 2012).

Ao tratar da relação entre direitos fundamentais e deveres fundamentais, Nabais (2012) pontua que ainda que os deveres fundamentais estejam fora da parte da Constituição dedicada

51 | Revista Brasileira de Direito Animal, e-issn: 2317-4552, Salvador, volume 15, n. 01, p.35-60, Jan-Abril 2020 
aos direitos fundamentais, ou seja, previstos nas partes que tratam da organização política, da economia e da sociedade, mesmo assim estão "a serviço da realização da dignidade da pessoa humana tendo em vista que esta é parte da comunidade estadual" (NABAIS, 2012, p.119). Explica que não há direitos sem deveres, porque não há garantia jurídica de direitos fundamentais sem o devido cumprimento dos deveres das pessoas humanas indispensáveis para o funcionamento da comunidade estatal. Assim, há uma "conexão funcional" entre direitos e deveres. Observa que o fato de os deveres fundamentais integrarem esse campo de jusfundamentalidade traz a importante consequência, de colocar subjacente aos deveres fundamentais a própria dignidade da pessoa humana. Nessa linha, os deveres associados aos direitos econômicos sociais e culturais transformam esses direitos em direitos-deveres, tornando-os funcionalizados, ou os transformando em uma categoria própria: os chamados direitos de solidariedade. Nabais (2012) coloca os direitos de proteção ecológica nessa última categoria, ou seja, como um direito-dever de solidariedade.

Nessa ótica, há uma conexão funcional entre o direito fundamental ao meio ambiente equilibrado no artigo 225, da CF/88, como pressuposto da dignidade da pessoa humana e o dever fundamental de garantir o equilíbrio ecológico, cujos destinatários são todas as pessoas titulares de responsabilidade comunitária, sejam pessoas naturais ou jurídicas, estas de direito público ou privado.

Sarlet e Fensterseifer citam Bosselmann (2001) quando este encarece uma influência recíproca entre direitos e deveres na relação do ser humano com o meio ambiente, tendo em vista que o ser humano, ao mesmo tempo em que necessita explorar os recursos naturais, também depende inteiramente deles para seu pleno florescimento. Assim, autolimitação do comportamento humano nessa relação é necessária não só para proteger os recursos naturais, mas também para garantir a própria dignidade da pessoa humana. É possível concluir então que o direito fundamental ao meio ambiente equilibrado é indissociável do dever fundamental de proteção ambiental previsto no artigo 225, da Constituição Federal do Brasil.

Ainda, não se pode olvidar que essa perspectiva dos direitos de solidariedade se apresenta como um grande avanço na visão liberal, pois desloca parcela da responsabilidade, do dever fundamental de proteção também para os particulares ensejando uma "transcendência individual" dos "direitos ambientais", que deixam de ser apenas direitos subjetivos para serem fontes de deveres e responsabilidades para com a proteção do meio ambiente (MATEO apud SARLET; FENSTERSEIFER, 2014, p. 243).

Dessa forma, é possível inferir do artigo 225 da Constituição Brasileira o direito de solidariedade decorrente da categoria jurídica dever fundamental, a que se refere Nabais (2012). Com efeito, é possível extrair do caput do artigo 225, da CF uma responsabilidade assimétrica consubstanciada no dever fundamental de assegurar o direito das gerações futuras ao meio ambiente equilibrado, isso, por si só, já representa um grande avanço. Todavia, a teoria do direito de solidariedade defendida por Nabais ainda se pauta em bases antropocêntricas, de modo que se precisa avançar para estabelecer uma solidariedade interespécies.

Nabais, ao tratar da proteção dos seres não humanos, plantas rios e mares não chega a abordar a proteção pelo caminho do reconhecimento de valor intrínseco e consequente titularidade de direitos, o faz pelo viés Kantiano dos deveres indiretos, reforçando o paradigma antropocêntrico. Sarlet e Fensterseifer (2014) sustentam que a Constituição no artigo 225, parágrafo primeiro, inciso VII, já superou essa visão kantiana de deveres indiretos, pois atribuiu um valor próprio a vida não humana, quando vedou expressamente as práticas cruéis para com os animais. Neste ponto, citam o escólio de Herman Benjamin para quem:

[...] o constituinte desenhou um regime de direitos de filiação antropocêntrica temporalmente mitigada (com titularidade também

52 | Revista Brasileira de Direito Animal, e-issn: 2317-4552, Salvador, volume 15, n. 01, p.35-60, Jan-Abril 2020 
conferida às gerações futuras), atrelado, de modo surpreendente, a um feixe de obrigações com beneficiários que vão além, muito além, da reduzida esfera que se chama humanidade. Se é certo que não se chega, pela via direta, a atribuir direitos à Natureza, o legislador constituinte não hesitou em nela reconhecer valor intrínseco, estatuindo deveres a serem cobrados dos sujeitos-humanos em favor dos elementos bióticos e abióticos que compõem as bases da vida. De uma forma ou de outra, o paradigma do homem como prius é irreversivelmente trincado. (BENJAMIN apud SARLET; FENSTERSEIFER, 2014, p. 263).

Com efeito, quando a norma do artigo 225 da CF/88 prescreveu o dever fundamental de preservação para assegurar o direito fundamental das gerações futuras, estabeleceu uma responsabilidade para comunidade de sujeitos de direito da atualidade abarcada pela expressão "todos" no início do caput, esta responsabilidade é assimétrica porque não está baseada na ideia contratualista de reciprocidade, na medida em que os sujeitos de direito das gerações futuras é uma potencialidade, uma virtualidade, assim não podem compor uma relação bilateral com os sujeitos do presente. Essa é a tônica dessa chamada "justiça intergeracional" (SARLET; FENSTERSEIFER, 2014, p. 259).

Sarlet e Fensterseifer (2014) criticam ainda a posição de Nabais (2012) no sentido de considerar juridicamente impossível a atribuição de direitos a titulares ativos virtuais que integram as gerações futuras, sob o argumento de que não seria adequado atribuir às gerações atuais deveres para com as gerações futuras, pois isso oneraria de forma desequilibrada a geração do presente. Percebe-se que dificuldade apontada por Nabais está na inexistência de reciprocidade, comutatividade nesse dever das gerações atuais para com as futuras. Essa dificuldade encontrada por Nabais decorre de sua visão antropocentrista e contratualista, pautada em uma responsabilidade simétrica e comutativa, entretanto Hans Jonas (2015) oferecenos uma proposta de dever para posteridade fora da noção de reciprocidade. Ele pontua que esse esquema não se presta para estabelecer um dever do ser humano em relação às gerações futuras. Esse dever não está pautado em uma reivindicação, pois aquilo que ainda não existe não faz reivindicações, mas nem por isso pode ter seus direitos usurpados. A reivindicação da existência só se inicia com existir, assim se propõe um dever pautado em uma ética que deve assegurar o direito do que ainda não existe. A responsabilidade que fundamenta esse dever é independente da ideia de direito e de reciprocidade. $\mathrm{O}$ autor cita a responsabilidade dos pais para com os filhos como exemplo de responsabilidade pautada em dever não recíproco e propõe um dever dessa natureza com relação ao futuro da Terra. Jonas (2015) fala em dever com a humanidade futura, este dever fundamental e assimétrico é o esteio da chamada solidariedade intergeracional albergada no artigo $225 \mathrm{da}$ CF/88.

A partir da mesma linha de raciocínio, pode-se postular, com base no princípio da solidariedade, uma responsabilidade assimétrica dos humanos para a proteção das demais espécies. Dessa forma, quando a norma do inciso VII parágrafo primeiro do artigo 225 estabelece um dever de proteção para como os animais e espécies ameaçadas de extinção, desse dever fundamental emerge um direito de solidariedade, pautado em uma responsabilidade também assimétrica e alheia ao esquema contratualista da reciprocidade. Nessa ótica, como ressaltam Sarlet e Fensterseifer (2014), já é possível identificar na constituição brasileira um princípio de justiça interespécies.

Como se vê, nossa constituição já caminhou em direção a um antropocentrismo temporalmente mitigado (BENJAMIN apud SARLET; FENSTERSEIFER, 2014, p. 263), de modo que nos parece viável o estabelecimento de um diálogo entre a proposta da "Earth Jurisprudence" de 
Burdon (2015), cujo propósito principal é a mudança do paradigma antropocêntrico, e as normas de proteção constitucional do meio ambiente na Constituição Federal brasileira.

Pois bem, Burdon (2015) esclarece que adota a expressão "Comunidade da Terra" de Thomas Berry porque ela traz a noção de que os ecossistemas envolvem os comportamentos individuais dos organismos, assim os organismos são considerados membros dos ecossistemas e não partes isoladas. O conceito de "Comunidade da Terra" traz, portanto, um eixo valorativo que influencia o sistema jurídico, não só ressignificando o conceito de lei, como também a forma como as leis são elaboradas.

Na perspectiva puramente antropocêntrica, a natureza não tem valor intrínseco e recebe uma valoração instrumental, como uma decorrência do direito de propriedade dos humanos. Para readequar o papel da natureza nas relações jurídicas, Burdon (2015) toma como ponto de partida o conceito de "integridade ecológica" da comunidade terrestre. Toda lei em matéria de direito ambiental, para ter qualidade, deve atender ao conceito de integridade ecológica, sob pena de autorizar os cidadãos a rejeitá-la, mediante desobediência civil pacífica. 0 conceito de "integridade ecológica" pode ser aferido pelos seguintes critérios: 1) capacidade autopoética de regeneração e evolução de vida ao longo do tempo em um local específico; 2) aferição das condições climáticas e outros fenômenos biofísicos; 3) influência da ciência ecológica sobre e as políticas públicas; 4) reconhecimento de valor intrínseco aos ecossistemas; 5) limitação do desenvolvimento humano e exploração da natureza.

Nesse diapasão, perquirimos sobre a possibilidade de atribuir ao significante "meio ambiente ecologicamente equilibrado", no enunciado prescritivo do artigo 225 , caput da CF, o significado axiológico de "integridade ecológica" acima proposto por Burdon (2015). É intuitivo que, para alcançar o equilíbrio ecológico, o meio ambiente deve estar apto à regeneração, com condições climáticas e biofísicas propícias ao florescimento da vida. Para tal, deve haver políticas destinadas à proteção, que se baseiam nas informações trazidas pela ciência ecológica. As políticas de proteção ambiental estão dentro do campo da chamada discricionariedade técnica, pois devem estar pautadas pelos dados científicos. As normas contidas no parágrafo primeiro, incisos I ao VII, da CF trazem em seus textos o valor "integridade ecológica" proposto por Burdon (2015), pois asseguram a preservação e restauração dos processos ecológicos. O inciso II do parágrafo primeiro do artigo 225 , da CF, refere-se expressamente em assegurar a diversidade e a integridade do patrimônio genético do país. O inciso III do parágrafo primeiro do artigo. 225, da $\mathrm{CF}$, ao tratar da definição de espaços de proteção, veda expressamente a utilização dessa áreas que venha comprometer a integridade dos atributos que justificam a sua proteção. O inciso IV do mesmo dispositivo prevê a necessidade de estudo de impacto ambiental para a instalação de obra ou atividade potencialmente causadora de degradação ao meio ambiente. $\mathrm{A}$ regra do inciso $\mathrm{V}$ do referido dispositivo limita o desenvolvimento humano que comporte risco para a vida, a qualidade de vida e do meio ambiente. O inciso VII, como já ressaltado, reconheceu o valor intrínseco dos animais, e da flora, na medida em que veda práticas cruéis e que coloquem em risco sua função ecológica.

Nessa perspectiva, o Poder Constituinte Originário ao atribuir esse dever fundamental de preservação do equilíbrio ambiental a "todos", incluiu nesse rol indeterminado também o poder constituinte reformador e o legislador em geral, o que implica reconhecer, que o legislador brasileiro, ao legislar, está jungido a essa intencionalidade: "meio ambiente ecologicamente equilibrado". Com maior rigor, ainda, o chefe do poder executivo na gestão das políticas ambientais está adstrito, não só aos limites formais que caracterizam o poder regulamentar, como ao limite substancial que regra também o seu poder discricionário para formular políticas ambientais. Isso significa dizer que a linha de gestão de política ambiental adotada pelo poder executivo deve, por imperativo constitucional, resguardar um "meio ambiente ecologicamente 
equilibrado", sob pena de descumprir um dever fundamental imposto pela Constituição e incorrer em crime de responsabilidade, previsto na Lei n. 1.079/50, no artigo 4, inciso V.

Verifica-se, portanto, que é possível vislumbrar na Constituição brasileira uma abertura semântica que permite a dialogia de seu texto normativo (GAMA, 2009) com o conceito de "Grande Lei" proposta por Burdon (2015), cujo conteúdo valorativo é a "integridade ecológica". Essa dialogia entre o texto normativo do artigo 225 da CF com o conteúdo axiológico da "integridade ecológica", que preenche a Grande Lei, nos permite construir uma nova linguagem no direito ambiental brasileiro, permeada pela significação da ética biocêntrica, que inclui, como destinatários do "bem comum" também os animais, as plantas e os ecossistemas.

A integridade ecológica só pode ser alcançada em uma "Comunidade Terrestre", que viva em harmonia e em respeito mútuo, esse respeito só verdadeiramente existe quando se atribui a todos os seres a consideração moral, a dignidade inerente, o valor intrínseco imanente ao "ser" e do qual a categoria das coisas é carecedora. Entre pessoa e coisa não existe uma relação ética pautada por juízos de justo e injusto; há, sim, vínculo jurídico de domínio e juízo de mera conveniência. Esse juízo de conveniência do proprietário da coisa é semelhante àquele exercido por Odisseu, quando determinou a morte de suas escravas por simples estratégia do exercício do poder, para causar temor, como conta-nos Aldo Leopold (LEOPOLD apud NASH, 1989), que usa esse trecho aterrador de "Odisseu Divino" para ilustrar que a coisificação dos animais, das plantas e dos ecossistemas, tem a triste consequência de excluí-los de nossa comunidade ética, e assim da titularidade de direitos e até mesmo respeito.

Por último, vale a observação de Sarlet e Fensterseifer (2014) no sentido de que que o artigo 1.228, parágrafo primeiro, do Código Civil de 2002, expressamente atribui a função ecológica da propriedade, ao prever que:

o direito de propriedade deve ser exercido em consonância com as suas finalidades econômicas e sociais e de modo que sejam preservados, de conformidade com o estabelecido em lei especial, a flora, a fauna, as belezas naturais, o equilíbrio ecológico e o patrimônio histórico e artístico, bem como evitada a poluição do ar e das águas (SARLET; FENSTERSEIFER, 2014, p. 269).

De fato, o direito humano a propriedade está condicionado pelo dever fundamental de preservação e manutenção do equilíbrio ecológico, dever fundamental tão intimamente associado ao direito de propriedade, que o transmuta em um direito-dever da manutenção do equilíbrio, da salubridade e da segurança ecológica em favor de toda a comunidade (SARLET; FENSTERSEIFER, 2014, p. 269).

Assim, mesmo que o ordenamento jurídico brasileiro ainda não atribua personalidade jurídica aos animais, às plantas e aos ecossistemas; com base na dialogia do conceito de "integridade ecológica" (BURDON, 2015), com os textos do artigo 225, parágrafo primeiro, incisos I a VII, e da CF e do artigo 1.228, parágrafo primeiro do Código Civil, que estabelece a função ecológica da propriedade, é possível construir uma nova linguagem e ampliar o horizonte jurídico brasileiro em direção à proposta de "Earth Jurisprudence" (BURDON, 2015).

\section{Conclusão}

Como já mencionado anteriormente, Thomas Kuhn (KUHN apud BURDON, 2015) advertiu-nos que um paradigma só pode funcionar se suas ferramentas ainda forem eficientes para resolver os problemas que ele define. Ora, o paradigma jurídico antropocêntrico consolidado quase como uma verdade absoluta pelos construtores da modernidade jurídica não está

55 | Revista Brasileira de Direito Animal, e-issn: 2317-4552, Salvador, volume 15, n. 01, p.35-60, Jan-Abril 2020 
funcionando e suas ferramentas, as categorias propostas pelo positivismo jurídico, não são mais eficientes para resolver o maior conflito jurídico que emerge nesta era, que a ciência está denominando "Atropoceno", o conflito entre os interesses egóicos do ser humano e a perpetuação da vida na Terra.

De fato, o paradigma jurídico antropocêntrico moderno se consolidou sobre um fundamento quase sagrado para o ser humano moderno, o direito de propriedade. Para resguardar esse sacro direito foram desenvolvidas categorias jurídicas como: sujeito de direito, direito subjetivo, domínio, autonomia privada, coisa, bem etc. A titularidade dos direitos apenas pelo ser humano tornou-se um dogma religioso, só os humanos podem ser sujeitos de direitos e titulares do direito de propriedade e do domínio sobre a Terra, os animais, as plantas e ecossistemas.

Esse arcabouço jurídico, com algum grau de variação nos ordenamentos, passou a ser predominante no mundo moderno e serviu de fundamento jurídico para os modelos econômicos. Ocorre que a realidade biológica, física e orgânica do planeta nos mostra um cenário de exaustão e de iminente escassez de energia, de modo que a realidade nos impele a uma urgente mudança de consciência necessária para salvar a própria espécie humana. Então, se o paradigma jurídico antropocêntrico foi criado para beneficiar os interesses da espécie humana, este já não atende mais seu propósito.

Nesse cenário dramático, em que os recursos naturais se esvaem, milhares de espécies são extintas todos os anos, onde a própria espécie humana tem a maioria de seus integrantes premidos pela miséria e pela violência, algo está errado e nos obriga a questionar o acerto dos dogmas jurídicos que elevaram apenas o ser humano à posição de dignidade e de sujeito de direito.

Assim, a ética ecológica profunda, emergente desde o segundo quadrante do século passado e que postula a consideração moral e titularidade de direitos também para os seres não humanos deve ser ouvida atentamente e examinada sem os dogmas da religiosidade judaicocristã, sem as amarras da racionalidade cartesiana. O fato de adotarmos a ética biocêntrica e reconhecermos direitos para animais, plantas e ecossistemas não compromete os nossos direitos humanos já reconhecidos, ao contrário, haverá um fortalecimento da dignidade do ser humano.

São várias as teorias de justiça ecológica que emergem na atualidade e que se apresentam como alternativa ao já esgotado paradigma puramente antropocêntrico. Acreditamos que a melhor saída é a busca de um paradigma que prime pela a harmonia entre os direitos humanos e o direito a autorrealização dos outros seres não humanos.

Neste artigo escolhemos examinar a chamada "Jurisprudência da Terra" de Tomas Berry, desenvolvida por Peter Burdon (2015), para verificar sua adequação a este momento de transição epistemológica, e verificamos que se trata de uma teoria de justiça ecológica que se harmoniza com o positivismo jurídico brasileiro e com os direitos humanos.

Chegamos a essa conclusão, ao estabelecermos o diálogo textual do modelo jus filosófico apresentado por Berry e desenvolvido por Burdon, denominado Jurisprudência da Terra, com o texto do artigo 225, parágrafo primeiro, incisos I a VII, da Constituição Brasileira. Essa intertextualidade demonstrou-nos adequada para a perfeita harmonização do dever fundamental de proteção previsto na Constituição de 1988, do qual decorre o direito de solidariedade, baseado na responsabilidade assimétrica de Jonas (2015) com os direitos humanos.

Ainda que o ordenamento jurídico brasileiro seja concebido e desenvolvido sob os auspícios da epistemologia jurídica puramente antropocêntrica, entendemos possível uma dialogia com os novos textos filosóficos, que emergem da ética biocêntrica, sendo que esse diálogo textual não solapa os direitos humanos já reconhecidos; antes, fortalece-os, na medida em que proteger o direito de outros seres, com os quais compartilhamos de forma 
interdependente a biosfera, só reforça a integridade biológica da humanidade sobre a qual se assenta aspecto relevante da própria ideia de dignidade da pessoa humana.

Consideramos adequada, para o avanço jurídico nesse sentido, a teoria dos deveres fundamentais constitucionais, que embasa o chamado direito de solidariedade, defendida por Nabais (2012). De fato, os "direitos de solidariedade" (NABAIS, 2012, p. 52) ou "direitos boomerang" (NABAIS, 2012, p. 53) harmonizam o dever fundamental de proteção ambiental com o direito humano ao meio ambiente equilibrado, tendo em vista que o dever fundamental, como uma categoria jurídica autônoma, está ao lado dos direitos fundamentais "a serviço da realização da dignidade da pessoa humana" (NABAIS, 2012, p.119).

Não obstante, a teoria de dever fundamental da qual decorre os direitos de solidariedade, sustentada por Nabais, ainda precisa evoluir no sentido de embasar essa responsabilidade fora dos moldes da reciprocidade, da comutatividade kantiana entre deveres e direitos. Para tal, adotamos a teoria da responsabilidade de Hans Jonas (2015), que possibilita a existência de um dever fundamental assimétrico das gerações presentes, albergadas na expressão "todos" no início do enunciado do artigo 225, da CF, em relação, não só às gerações futuras de humanos, como também para proteger os seres não humanos, as plantas e ecossistemas.

Nessa linha, a construção interpretativa, a partir dos enunciados do artigo 225 caput e, parágrafo primeiro incisos I, VII, da CF, de um eixo valorativo constitucional, cujo conteúdo amolda-se ao conceito de "integridade ecológica" proposto por Peter Burdon, apresenta-se como um novo horizonte interpretativo fundado no reconhecimento de valor intrínseco aos animais, plantas e ecossistemas e que vincula, pelo dever fundamental de proteção ambiental, pautado em uma responsabilidade assimétrica, não só os particulares na titularidade do direito de propriedade e como usuários de recursos naturais, mas também os três poderes do Estado.

Embora, nosso ordenamento jurídico não reconheça a titularidade subjetiva de direitos para os animais, plantas e ecossistemas, concluímos ser possível extrair de nossa Constituição, a partir do eixo valorativo da 'integridade ecológica' (BURDON, 2015) e da categoria jurídica dever fundamental (NABAIS, 2012), da qual decorre os direitos de solidariedade, o reconhecimento de valor intrínseco aos animais, plantas e ecossistema.

Esse dever fundamental de proteção, corroborado pela responsabilidade exasperada do ser humano, nos termos propostos por Hans Jonas (2015), representa um largo passo em direção a um novo paradigma, que harmoniza o reconhecimento de valor intrínseco à Natureza com o direito da pessoa humana ao pleno florescimento.

Notas de Referência

AQUINAS, Thomas. Summa Contra Gentiles, apud BURDON, Peter. Earth Jurisprudence, Private Property and the Environment. New York: Routledge, p. 85, 2015.

ARENDT, Hannah. A Condição Humana. 10 ed. Rio de Janeiro: Forense Universitária, p. 91, 2007.

ARISTÓTELES. Ética a Nicômaco apud COMPARATO, Fábio Konder. Ética, Direito, Moral e Religião no Mundo Moderno. São Paulo: Companhia das Letras, 2006.

ARTEGA-CRUZ, Erika Lorena. Buen vivir (Sumak Kawsay): definiciones, crítica e implicaciones en la planificación del desarrollo en Ecuador. Saúde Debate. Rio de Janeiro, n. 114, v. 41, pp. 907-919, 2017. 
AUGUSTYN, Prisca. Animal Studies in the Language Sciences. Biosemiotics. [S. I.]: Springer, [s. n.] v. 11, pp. 121-138, 2018.

BENJAMIN, Antônio Herman. Constitucionalização do Ambiente e Ecologização da Constituição Brasileira. In. CANOTILHO, José Joaquim Gomes; MORATO LEITE, José Rubens (orgs.). Direito Constitucional Ambiental Brasileiro. São Paulo: Saraiva, 2007.

BERRY, Thomas. Dreamer of the earth, the spiritual ecology of the father of environmentalism. Toronto: Inner Traditions, 2011.

. Legal conditions for Earth survival. In: TUCKER, Mary-Evelyn. Evening Thoughts: Reflections on Earth as Sacred Community. San Francisco: Sierra Club Books, 2006.

. The Dream of the Earth. San Francisco: Sierra Club Books, 1988.

. 'The New Story' in Teilhard Studies apud BURDON, Peter. Earth Jurisprudence, Private Property and the Environment. New York: Routledge, p. 68, 2015.

BOSSELMANN, Fred P.; TARLOCK, A.D. The Influence of Ecological Science on American Law: An Introduction. Chicago Kent Law Review, [S. I.], [s. n.], [s. v.], 1994.

.Human Rights and the Environment: the search for common ground. Revista de Direito Ambiental, n.23, p. 35-52.São Paulo. Revista dos Tribunais, jul.-set.2001.

BOYD, David R. The rights of Nature, a Legal Revolution that could save the world. Toronto: ECW Press, 2017.

BURDON, Peter. Earth Jurisprudence, Private Property and the Environment. New York: Routledge, p. 80, 2015.

CHIVIAN, Eric; BERNSTEIN, Eric. Sustaining life: how human Health depends on Biodiversity. New York: Oxford University Press, 2008, apud SCHIMELPFENIG, Robert. The Drama of the Anthropocene: can Deep Ecology, Romanticism, and Renaissance Science Rebalance Nature and Culture?. The American Journal of Economics and Sociology. [S. I], n. 4, v.76, set. 2017.

CORMAC, Cullinam. Wild Law: A Manifesto for Earth Justice. In: BURDON, Peter. Earth Jurisprudence, Private Property and the Environment. New York: Routledge, p. 80, 2015.

COMPARATO, Fábio Konder. Ética, Direito, Moral e Religião no Mundo Moderno. São Paulo: Companhia das Letras, 2006.

CRUTZEN, Paul J.; STOERMER, Eugene F. The Anthropocene. Global Change Newsletter. Stockholm: The Royal Swedish Academy of Sciences Box, [s. n.], v. 40, p. 17, 2000.

CULLINAN, Cormac. Wild Law. África do Sul: Siber INK, 2011.

Wild Law: A manifesto for Earth justice. Totnes: Green Books, 2003.

58 | Revista Brasileira de Direito Animal, e-issn: 2317-4552, Salvador, volume 15, n. 01, p.35-60, Jan-Abril 2020 
D'AMOUR, Bren; REITSMA, Femke; BAIOCCHI, Giovanni; BARTHELE, Stephan; G€UNERAL, Burak; ERB, Karl-Heinz; HABER, Helmut; SETOI, Karen C. Future Urban Land Expansion and Implications for Global Croplands. Proceedings of the National Academy of Sciences December. [S.I], [s. n], [s. v.], 2016, apud SCHIMELPFENIG, Robert. The Drama of the Anthropocene: Can Deep Ecology, Romanticism, and Renaissance Science Rebalance Nature and Culture?. The American Journal of Economics and Sociology. [S.I.], n. 4, v. 76, 2017, DOI: 10.1111/ajes.12196 https://doi.org/10.1111/ajes.12196.

DE MIRANDA, Evaristo Eduardo. A Água no corpo humano. Meio Ambiente News. [S.I], [s. n.], 2004. Disponível em: http://www.meioambientenews.com.br/conteudo.ler.php?q\%5B1\%7Cconteudo.idcategoria\%5D= 27\&id=215. Acesso em: 11 nov. 2019.

DOUZINAS, Costas. O Fim dos Direitos Humanos. São Leopoldo: Editora Unisinos, 2009.

FINNIS, John. Nature Law and Natural Right. Oxford: Clarendon, 1980.

GAMA, Tácio Lacerda. Sentido, Conscistência e Legitimação. In: HARET, Florence; CARNEIRO, Jerson-Noeses. Vilém, Flusser e Juristas. São Paulo: Noeses, p. 244, 2009.

GIAMBATTISTA, Vico. The New Science. [S. I]: Cornell University Press, 1976.

GORDILHO, Heron José de Santana, SILVA, Raissa Pimentel Silva. Os Animais, a Natureza e as Três Ecofilosofias. Revista de Biodireito e Direito dos Animais. Brasilia, v.2. p.1-19, jan-Jun.2016.

GROTIUS, Hugo. O Direito da Guerra e da Paz. 2. ed., v. I e II. Ijuí: Unijuí, 2005.

HART, H. L. A.. The Concepto of Law. In: DOUZINAS, Costas. O Fim dos Direitos Humanos. São Leopoldo: Editora Unisinos, 2009

HOBBES, Thomas. Leviatan. Bambridge: Cambridge University Press, 1996.

. Leviatan. Bambridge: Cambridge University Press, 1996. In: VILLEY, Michel. A formação do pensamento jurídico moderno. São Paulo: Martins Fontes, 2009.

JONAS, Hans. O Princípio da Responsabilidade. Rio de Janeiro: PUC-RIO, 2015.

KANT, Emmanuel. Crítica da Ração da razão prática apud COMPARATO, Fábio Konder. Ética, Direito, Moral e Religião no Mundo Moderno. São Paulo: Companhia das Letras, 2006.

KUHN, Thomas. The Structure of Scientific Revolutions apud BURDON, Peter. Earth Jurisprudence, Private Property and the Environment. New York: Routledge, p. 89, 2015.

LEOPOLD, Aldo. The Rights of Nature, A History of Environmental Ethics apud NASH, Roderick Frazier. The Rights of Nature, A History of Environmental Ethics. Winsconsin: The University of Wisconsin Press Madison, 1989.

LON, Fuller. Human Purpose and Natural Law. Journal of Philosophy. [S.I], [s. n.], [s. v.], 1956. 
MORIN, Edgar. Ensinar a viver: manifesto para a educação. Porto Alegre: Sulina, 2015.

NABAIS, José Casalta. O Dever Fundamental de Pagar Impostos: contributo para a compreensão constitucional do estado fiscal contemporâneo. Coimbra: Almedina, 2012.

PLOTKIN, Bill. Inscendence: The Key to the Great Work of Our Time A Soulcentric View of Thomas Berry's Work. In: BERRY, Thomas. Dreamer of the Earth, the Spiritual Ecology of the Father of Environmentalism. Toronto: Inner Traditions, pp. 48-71, 2011.

RULL, V. The "Anthropocene" uncovered. Collectanea Botanica. Barcelona, [s. n.], v. 36, p. 3, 2017.

SARLET, Ingo Wolfgang; FENSTERSEIFER, Tiago. Direito Constitucional Ambiental: constituição, direitos fundamentais e proteção do ambiente. São Paulo: Editora Revista dos Tribunais, 2014.

. Direito Ambiental: introdução, fundamentos e teoria geral. São Paulo: Saraiva, 2014

SCHIMELPFENIG, Robert. The Drama of the Anthropocene: can Deep Ecology, Romanticism, and Renaissance Science Rebalance Nature and Culture?. The American Journal of Economics and Sociology. [S. I], n. 4, v.76, set. 2017.

STONE, Christopher. Should Trees Have Standing? Toward Legal Rights for Natural Objects. In: DOUZINAS, Costas. O Fim dos Direitos Humanos. São Leopoldo: Editora Unisinos, 2009.

STOPPANI, A. Corso di Geologia. v. 3. Milano: G. Bernardoni e G. Brigola, 1873.

TAYLOR, Paul W. Respect for Nature: A Theory of Environmental Ethics. New Jersey: Princeton University Press, 2011.

THONGMARK, Seri; HULSE, David L.. Os Ventos da Mudança: As pessoas Karem em Harmonia com o Patrimônio Mundial. In: CULLINAN, Cormac. Wild Law. África do Sul: Siber INK, 2011.

TRIGUEROS, Alezah. The human right to water: will its fulfillment contribute to environmental degradation?. Indiana Journal of Global Legal Studies. [S. I.], n. 2, v. 19, 2012.

UN. Resolution adopted by the General Assembly on 28 July 2010 n. 64/292 The human right to water and sanitation. New York, 28 jul. 2010. Disponível em: https://www.un.org/en/ga/search/view_doc.asp?symbol=A/RES/64/292. Acesso em 15 nov. 2019.

VILLEY, Michel. A formação do pensamento jurídico moderno. São Paulo: Martins Fontes, 2009.

WEBER, A. Alles Fühlt. Mensch, Natur, und die Revolution der Lebenswissenschaften. In: AUGUSTYN, Prisca. Animal Studies in the Language Sciences. Biosemiotics. [S. I.]: Springer, [s. n.], v. 11, pp. 121-138, 2018. 